\title{
セルロースの新しいプロセッシング エース復活へのニューパラダイム
}

\author{
山根千引厶 热化成(株)高分子科学研究所
}

環境問題への対応や天然素材への関心などから, 再生セルロース繊維の新しいプロセッシ ングにより新たな繊維が生み出されている. その一つがセルロースの溶解に苛性ソーダし か使用しない，セルロース／aq. $\mathrm{NaOH}$ 系原液からの繊維である．新セルロース繊維の性 能は既存の再生セルロース繊維と同等かそれ以上であった.

\section{1.はじめに}

化石燃料の有限性, 合成樹脂の廃棄問題などの観点か らリニューアブルで分解性の高いセルロースを見直す気 運が世界的に高まり，セルロースの構造・物性・機能な どに関する学術的研究が年々盛んになっている. それに ともない, 1984 年以降，セルロース国際会議 (Cellucon)がほぼ毎年開催されたり，日本においても，昨年の 京都セルロース国際会議 (Kyoto Conference on Cellulosics) の開催やセルロース研究会（1995 年 6 月以降セ ルロース学会に改称）の設立など学術交流の場も増え た.この学術交流の隆盛にとむない, セルロースの応用 展開も急速には加られ, 従来の添加剤といった, 脇役的 存在から, ウィルス除去膜, 経口徐放性薬剂などのよう な高機能性材料として多岐の分野で使用されるようにな った1)

一方，セルロース工業としては最あ歴史のある再生セ ルロース瀻維に目を転じると, その生産量は近年横ばい 傾向にはあるあのの, 現在なお, 主にビスコース法, 銅 アンモニア法の二方法によって, 長繊維 (フィラメン ト), 短織維 (ステープルファイバー) 合わせて世界の全 䋐維生産量の約 $6.5 \%$ にあたる, 年間約 250 万トンが生 産されている2゙. フィラメントの生産技術に注目すると, 例えば労働生産性は, 日本における最初の工場の 1000 倍, 1960 年代以降約 10 倍など, 対数的に向上してお $り^{3)}$, 特許によれば紡糸速度は, 毎分 $1500 \mathrm{~m}$ に達するな ど長足の進歩をとげだ). しかし，製造プロセスにおいて 有毒ガスや物質が発生するため, これらの回収・処理に 多大なコストを要すること, 水やエネルギーを大量に消 費するなどの基本的問題は, まだ残されている.

それらの問題に対処するためにさまざまな有機溶媒を

New Processing of Regenerated Cellulose Fiber
使ったクローズドシステムの研究が進められてきた5). しかし [セルロース/アミンオキサイド/水］混合系以 外のほとんどすべての系は, 溶媒自身の高い毒性, 爆発 性を持つ副生成物の生成, 溶媒回収の困難さなどの工業 的な視点から，いまだ成功していないのが現状である.

[アミンオキ+イド/水］システムはコートルズ社によ り企業化され，米国アラバマ州モービルの工場で 1992 年より商業生産 (商品名「テンセル」) が開始され, 現在 の生産能力は 18,000 トン/年であるが, 1995 年夏には 43,000トン/年に引き上げられるとアナウンスされて いる6).「テンセル」は従来の再生セルロース䋳維に比べ, 特に湿潤時の機械的物性が高い. 同時にフィブリル化し やすいという性質を有するが，これを生かした製品展開 がはかられている。

一方, 苛性ソーダを溶媒としたセルロース䋐維の開発 により可食性セルロース繊維「セキセル」7) が 1988 年に 旭化成により上市された，衣料用の繊維についてもべン チスケールの製造技術が確立された ${ }^{8}$. セルロースの溶 解には, 水酸化ナトリウムしか必要としないため, 作業 環境や地球環境的問題の拔本的解決はもとより, 使用薬 品コストの低減, 排ガス処理の不要, 回収コストの不要, 排水処理コストの大幅な低減が期待できる.ここでは, このアルカリ水溶液を溶媒とした新セルロース織維のプ ロセッシングについて概説する.

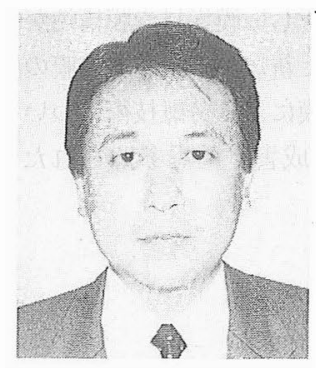

山根千弘 旭化成(株)高分子科学 研究所 (569 高柣市八丁叕町 11-7）研究員

1985 年北大工学部応用化学科修 士課程修了. 同年旭化成入社, 七 ルロース織維の固体構造に関する 研究に従事.

〈趣味〉スキー, 山登り 


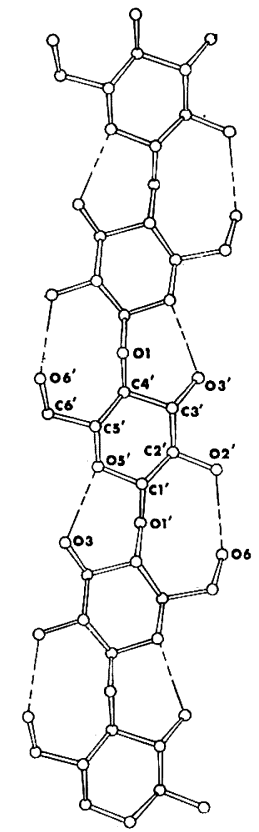

図 1 セルロースの分子内水素結合

\section{2. アルカリ水溶液を溶媒とした新セルロース繊維}

\section{2-1. セルロースのアルカリ可溶化}

セルロースはアルカリ水溶液に膨潤し部分的に溶解し ても完全には溶解はしないと長年信じられてきた。 セル ロースをザンテート化（エステル化）したり（ビスコー ス法), 銅アンモニア錯体化（銅アンモニア法）するのあ セルロースをアルカリ可溶化するためのあのであった. セルロースを構成するグルコピラノース単位は 3 個の 水酸基を持つので，セルロースの水酸基密度はポリビニ ルアルコールなどに比べて高く, 化学構造的には完全に 水に溶けてあおかしくはない，しかしながら， $\mathrm{OH}$ 基が 多い分，分子内扰よび分子間の水素結合性も高く，水系 溶媒への溶解性が阻害されている，特にセルロースの

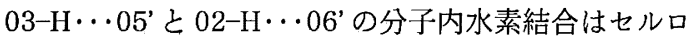
一スをいわばラダーポリマー状（図 1）にして, 溶解性 を著しく低下させている可能性がある．この分子内水素 結合を切断すればセルロースはアルカリ水溶液に可溶化 するはずであるというのがセルロースのアルカリ可溶化 の発想である.

最初の可溶化は再生セルロースを用いてなされた。 セ ルロース/銅アンモニア溶液を凝固法を変えて再生する と, 溶解性は凝固法に大きく依存し，アセトンを凝固剂 としたときのみ $\mathrm{NaOH}$ 水溶液に $100 \%$ 溶解した ${ }^{9}$. それ ぞれの凝固物の $\mathrm{X}$ 線結晶化度, 重水素化 IR 法で評価し たアクセシビリティー, $\mathrm{CP} / \mathrm{MAS}{ }^{13} \mathrm{C}-\mathrm{NMR}$ から求め

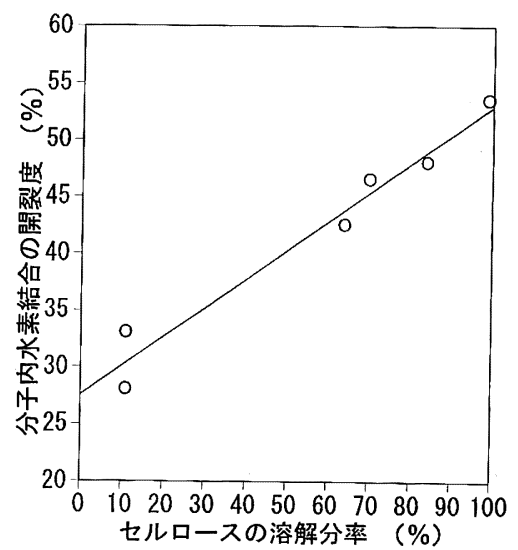

図 2 分子内水素結合の開裂度とセルロースの溶解 分率 ${ }^{14)}$

た分子内水素結合の開裂度合い等のさまざまな構造パラ メー夕と溶解性の関係を調べたところ, 分子内水素結合 の開裂度合い之溶解性だけが良く相関し, 前述のアルカ リ可溶化の仮説を支持する結果が得られた。.また，希薄 溶液に関する研究加，セルロースは誘導体や錯体を形 成せずに分子分散していることも証明された ${ }^{10)}$. しか し，苛性ソーダをセルロースの溶媒として広く工業的に 利用するためには，天然セルロースを可溶化する必要が あった．そのためにわれわれは爆砕処理法を用いた。

爆砕法は, 高温の飽和水蒸気を物質の内部に染み込ま せた状態から，急激に大気圧下に物質を開放する处理で

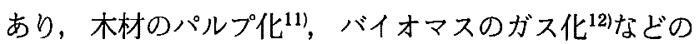
バイオマス化の有効利用技術として広く利用されてき た．この爆砕法をパルプなどの天然セルロースに適用す ると，分子内水素結合を切断できることが判り，その結 果, 商業的に利用可能なセルロース源加らルカリ可溶 セルロースを得ることができたのである ${ }^{13)}$ ．そして，図 2 に示すように, アルカリ水溶液への溶解性あ再生セル ロース同様, 分子内水素結合の開裂度合に支配されるこ とあ証明した ${ }^{14)}$.

\section{2-2. 工業的な溶解技術}

少量のセルロース/アルカリ水溶液系を扱う実験では 徹底したろ過操作によりゲルフリーな溶液が調製できる が，大量でしかも比較的高濃度の溶液を取り扱う際に は，万過技術に限界がありセルロースの溶解性の向上は 不可欠である. 例えば, 衣料用フィラメントの製造紡糸 工程での切れ糸は糸の長さ 1000 万メートル当たり 1 回 以下でなければならない，さらに系の長さ方向には太 さ, 力学的性質および染色性などが均一なことが要求さ れる.これらの条件が満足されないと，その織維を織物 にしたときの織物品位は著しく低下する，糸の均一性を 
確保するのに，最む重要で基本的なことはセルロースの 溶解技術である．ビスコースレーヨンフィラメントの紡 系に打いては, セルロースの溶解分率は, 工業的規模で は少なくとも $99.9 \%$ 以上必要である。これはビスコー スレーヨンでは紡系ノズルの直径は $50 \mu \mathrm{m}$ 前後と細い ため, 未溶解物がわずかであ存在すると, ドープの吐出 が不安定になり，均一な系を作ることが困難になるばか りかノズルが閉塞し紡系不能になるためである.

セルロースのアルカリ水溶液への溶解速度は非常に遅 (15). 溶解初期には, 溶解は拡散律速で進行するあのの, 拡散抵抗が時間とと屯に比例的に増大し溶解速度は急激 に遅くなり，最終的には溶解は見かけ上停止する．この ため, 溶解を完全に進めるためには溶解過程で形成され る拡散速度の遅い首を削り取るための高せん断，高速か くはんが必要である。 ただし，平衡的にはセルロースは 低温ほど溶解性がよいので, 工学的な溶解のポイントは 温度の上昇を抑えて, できる限りの高せん断, 高速かく はんを行うことである.

A. Cuculo $ら^{16)}$ は, $8.5 \mathrm{wt} \%$ の $\mathrm{NaOH}$ 水溶液に天然セ ルロースを溶解させたが，セルロースの溶解分率はわず か 34.56\%に留まっている，彼らは溶解分率を上げるた め, セルロースの結晶形をセルロースIIIに変えたり， 添加物を検討したが，それでも溶解分率は $70 \%$ を越え なかった。これは， $-5^{\circ} \mathrm{C}$ で所定時間静置したり，セル ロース $/ \mathrm{NaOH}$ 水溶液の凍結と解凍を繰り返す ( Temperature cycling technique) だけで, 溶解速度と溶解の 現象論的側面を考慮しなかったためでもあろう。

実際の溶解工程では, 高速かくはんにとあなう摩擦熱 で温度が上昇する前に溶解を完了させることを目的に， あらかじめ爆砕パルプを徹底的に微細化し表面積を上 げ,さらに 1 5 wt\% の希薄アルカリ水溶液にあらかじ め浸漬して溶解反応を速める工夫をしている．表面積を 上げる方法にはパルプをフィブリル状にすることも有効 であるが粘度が高く高速かくはんには不向きである，溶 解機はデッドスペースの少ない高速かくはんミキサーを 使用しており，平均滞留時間 (溶解時間) は 1 秒以内に
設定している，以上の溶解技術により, 粘度平均重合度 320 以上で，セルロースフィラメントを工業的に製造で きる溶解レベルの, 溶解分率 $99.9 \%$ 以上を達成するこ とができた8). 得られたセルロース/アルカリ水溶液は 30 日以上安定であり, 安定性の面加も, 工業的利用に 問題ないレベルであった.

\section{2-3． 新セルロース繊維の製造技術}

フィラメントを工業的生産する上で重要な課題は紡系 速度を向上させることである. 衣料用フィラメントは一 般的に 200 デニール（糸 $9,000 \mathrm{~m}$ 当たりの重さ $\mathrm{g}$ ) 以下 と軽く, 紡系速度を上げる以外に設備生産性を上げる方 法がないからである，望ましい紡系速度は得られる糸の 品質, 設備コスト、生産量, 糸の值段などを総合的に判 断し決定されるべきだが, 紡糸速度が低すぎると 1 鍾あ たりの設備コストの圧縮や売值の設定値アップなど事業 化を考える際の選択肢が少なくなることは確かである.

紡糸速度が上がると, 凝固液と系との摩擦抵抗が増 し, 糸にかかる張力増加のため最後は糸切断にいたる. 紡系速度向上のポイントは, 凝固過程の系の強度と紡系 抵抗を軽滅することにある。

湿式紡系の従来の紡系速度向上策は, ビスコースレー ヨンフィラメントでは直管流管の流動浴紡系法, キュプ ラアンモニウムレーヨンフィラメントでは流下緊張紡系 法などであり，それぞれ毎分 $850 \mathrm{~m}^{17)}, 1500 \mathrm{~m}^{4)}$ の紡系 速度を得ている. しかし従来の方法では, 凝固液と糸の 摩擦抵抗を減じることはできるが, それ以外の張力発生 要因を取り除くことはできない。

図 3 に新しく開発した，低張力で紡糸できる新セルロ 一ス䋐維の紡系装置を含む製造プロセスを示す ${ }^{18}$ )。この 装置は従来のビスコースレーヨンフィラメントで採用さ れている高速紡糸用の直管流管と, 紡系速度とほぼ等し い表面速度で走行するネットを組み合わせたすのであ る.この装置では, 直管流管内の凝固液の速度とネット の表面速度を等しくすることや，凝固液を系をネットで 下支えした状態でサクションにより除去することによ り, 紡系速度を上げる際の障害となる, 凝固液と糸の摩

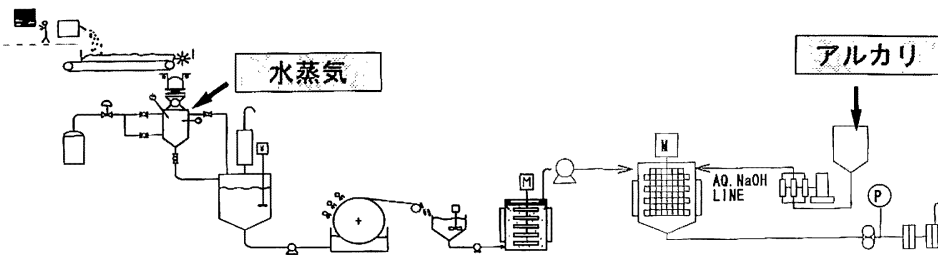

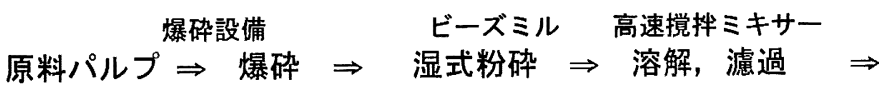

ネット直接紀系機

紡糸

図 3 セルロース/aq. $\mathrm{NaOH}$ 系セルロース繊維製造プロセス 
表 1 繊維および織物の物性 ${ }^{18)}$

\begin{tabular}{|c|c|c|c|c|c|c|c|c|}
\hline & \multicolumn{4}{|c|}{ フィラメント } & \multicolumn{4}{|c|}{ 織物*2 } \\
\hline & $\begin{array}{l}\text { 乾強度 } \\
(\mathrm{g} / \mathrm{d})\end{array}$ & $\begin{array}{c}\text { 乾伸度 } \\
(\%)\end{array}$ & $\begin{array}{c}\text { 弾性率 } \\
(\mathrm{g} / \mathrm{d})\end{array}$ & $\begin{array}{l}\text { 膨潤度*1 } \\
(\%)\end{array}$ & $\begin{array}{c}\text { 湿摩擦 } \\
\text { 堅牢度 } \\
\text { (級) }\end{array}$ & $\begin{array}{l}\text { 耐光 } \\
\text { 堅军度 } \\
\text { (級) }\end{array}$ & $\begin{array}{c}\text { 剛軟度 } \\
(\mathrm{cm})\end{array}$ & $\begin{array}{c}\text { 防しわ性 } \\
(\%)\end{array}$ \\
\hline 新セルロース繊維 & & & & & & & & \\
\hline $\begin{array}{l}\text { セルロース/aq. } \mathrm{NaOH} \text { 系 } \\
\text { ビスコース }\end{array}$ & 1.9 & 15 & 110 & 50 & $2 \sim 3$ & 4 & 3.8 & 59 \\
\hline $\begin{array}{l}\text { レーヨン } \\
\text { キュプラ }\end{array}$ & 1.8 & 18 & 80 & 100 & $2 \sim 3$ & 5 & 4.4 & 47 \\
\hline レーヨン & 2.7 & 11 & 130 & 80 & 3 & 5 & 4.4 & 56 \\
\hline
\end{tabular}

*1 重量法, $25^{\circ} \mathrm{C}, * 2$ 織物の試験は JIS L 842 1096 にしたがって行った

擦抵抗を含む各種紡糸張力を理論的にはゼロにすること ができる.

得られた新セルロースフィラメントの乾強度は 1.9 $\mathrm{g} / \mathrm{d}$, 乾伸度は $15 \%$ であり, 市販のレギュラービスコー スレーヨンフィラメント以上の基本物性である. 耐フィ ブリル性，キュプラアンモニウムレーヨンより優れてい た。また，現在の再生セルロースフィラメントの主な用 途である織物についてあ従来品並みの特性は確保でき, （表 1)，アルカリ可溶セルロースを用いたプロセスで代 替可能であることを確認した ${ }^{18)}$.

\section{2-4. 食品分野への応用}

セルロース／aq. $\mathrm{NaOH}$ システムはセルロースの溶解 に苛性ソーダしか使用しないために本質的に環境に優し く安全なシステムである，そのため食品分野などにあ展 開できる. セルロース／aq. $\mathrm{NaOH}$ 水溶液に，多糖など のゲスト成分を混合, 分子分散させた原液から食物繊維 「セキセル」を製造し，販売中である7?.「セキセル」は孔 径 $1 \mu \mathrm{m}$ 以下の微細な網目多孔構造を持つ䄉維であり, 保水・保油性, 形態保持性などの特性を持つ. 主な用途 は, 水練製品, 調理加工品, 小麦粉分野であるが，その 他，練りワサビ，おろししょうが等の練り調味料，ッナ フレーク，塩辛等のドリップ防止や䋐維感の付与の目的 で使われている。

工業的な溶解技術の検討過程でクリーム状セルロース

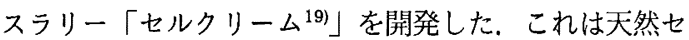
ルロースを平均粒径 $0.5 \mu \mathrm{m}$ まで細汃くして, 水に分散 させたクリーム状の新食品素材である. 人間の舌がざら つき感を感じると言われている粒径 $3 \mu \mathrm{m}$ をはるかに下 廻る粒径であり，動物油脂や油／水型エマルジョンと酷 似した食感を持つため，完全ノンカロリーな脂肪代替物 質として市場開拓中である. 特にマヨネーズ，マーガリ ン, ドレッシング，ホイップクリームなどの低脂肪化へ の展開が期待されている.

セルロース/aq. $\mathrm{NaOH}$ システムは環境に優しいだけ ではなく, 誘導体化工程や回収工程が不要なシンプルな
設備構成である，そのため, 食品分野に限らず, 䋐維, フィルム，コーティングなどセルロース成形品の少量多 品種生産プロセスにあ適すると考えている.

\section{3.おわりに}

再生セルロース䋐維は吸湿性, 風合い, 光沢に優れ, 合成䋡維にはない特徴があり，そのうえ天然素材への関 心や先に述べた「テンセル」などの新しい繊維の登場な どで見直しの気運にある，これを一時のブームに終わら せないためにも，環境問題などの基本的課題をクリアー し，セルロースの機能む，さらに上げていかねばならな いと考えている.

\section{文献}

1）例えば, 宮本武明：Cell. Commun., 1[1] 2 (1994)

2）日本化学織維協会，織維ハンドブック，1993

3）上出健二：䋊維産業発達史概論，日本繊維機械学会，(1993), p. 444

4）特開昭 61-19805: 旭化成

5) 大野泰雄, 林 治助：綫学誌，40,130 (1984)

6) 小林信吉: Cell. Commun., 1[2] 17 (1994)

7) 特開昭 62-64841: 旭化成

8) 山根千弘, 斉藤政利, 岡島邦彦：䋞維学会誌入投稿中

9) K. Kamide, K. Okajima, T. Matsui, K. Kowsaka: Polym. J., 16, 857 (1984)

10) K. Kamide, M. Saito, K. Kowsaka: Polym. J., 19, 1173 (1987)

11) H. Mamers, D. Menz, P. J. Menz: Appita, 33, 201 (1979)

12) R. H. Leitheiser, B. R. Bongner, F. C. Grant-Acquah: Proc. Symp. Wood Adhesives Research, Application and Needs, USDA Forest Products Laboratory, P-50 (1980)

13) T. Yamashiki, T. Matui, M. Saitoh, K. Okajima, K. Kamide: Brit. Polym. J., 22, 73 (1990)

14) K. Kamide, K. Okajima, K. Kowsaka: Polym. J., 24, 71 (1992)

15）山根千弘, 斉藤政利，岡島邦彦：䋊維学会誌一投稿中

16) B. Laszkiewicz, A. Cucuro: J. Apple. Polym. Sci., 50, 27 (1993)

17) 特開平 1-111005, 特公平 3-70006: 旭化成

18）山根干弘，齊藤政利，上阪圭介，片岡直樹，相良和経，上出 健二: Proc. '94 Cellulose R \& D, P. 183 (1994)

19) フードケミカル 11 月 P. 23 (1991), 特開平 3-163135 